\title{
Effect of some soil media types and growth regulators on lolium perenne
}

\author{
Abdou, M. A. H. ; Badran, F. S. ; Taha, R. A. and Hussain, H. M. \\ Hort. Dept., Fac. of Agric., Minia Univ.
}

\begin{abstract}
The present study was designed to explore the possibility of growing Lolium perenne turf grass in sandy amended soils rather than clay soil. In addition to reducing the expensive costs and time consumption due to frequent clipping by the application of some growth retardants. Four growing media types were tested (clay, sand, sand / clay and sand / compost). While cycocel and alar were foliar sprayed, three times at four weeks intervals at the concentrations of 1000 and $2000 \mathrm{ppm}$ for each one.

Growing Lolium perenne in clay soil greatly and significantly gave rise to the four tested vegetative growth parameters (plant height, covering density \% and fresh and dry weights) as well as, the three photosynthetic pigments over the other three growing media types. On the other hand, sandy soil resulted consistently, in the lowest values, while the two amended sandy soil gave intermediate records.

The four growth retardant treatments caused a considerable reduction in plant height and fresh and dry weights of the clippings, while resulted in remarkable increase in covering density \% as well as, stimulated photosynthetic pigments. Meanwhile, alar proved to be more effective than cycocel in this concern.

The interaction between growing media types and growth retardant treatments was almost significant for different vegetative growth parameters and photosynthetic pigments.

It is recommended to grow Lolium perenne turf grass in sand / compost $(2: 1 \mathrm{v} / \mathrm{v})$ amended growing media with the supplement of triple applications of alar at $2000 \mathrm{ppm}$ in order to obtain reasonable reduction in plant height, along with a desirable and fast covering density \% .
\end{abstract}

Keywords: Lolium perenne, turf grass, growth retardants, covering density .

\section{Introduction}

Lolium perenne, L. perennial ryegrass, fam. Graminea (Poaceae) is the solely cool-season turf grass grown in Egypt as winter annual turf grass. It is temporary turf grass under Egyptian climate. It grows fast and is used for quick cover, for erosion control and as winter grass on bermuda lawns. Most of it dies out in a years time (Williamson, 1975).

Turf grasses are known to grow successfully in clay loamy soil, but because of establishing many private and public gardens in the new areas, which characterized with sandy soils. It was urgent to explore the possibility of growing such turf grass in these sandy and amended sandy soils.

Many investigators indicated that the addition of compost to the sandy soil enhanced various vegetative growth parameters and chemical composition of Lolium perenne such as Barker (2001), Lawson (2002), Khalil et al., (2004), Montemurro et al., (2004) and Schnell et al., (2009).

On the other side, the problem of frequent mowing, which is expensive and time consuming was arisen. So, it is through to use some plant growth retardants, like cycocel or alar, which known to retard plant height but promote lateral branching and covering density, which means cut off the extensive labor and save money.

Manoly (2000) on bermuda grass revealed that both growth retardants, cycocel and alar, especially at higher concentrations (2000 and 4000 ppm ,respectively ) decreased plant height, clipping fresh and dry weights, but increased the covering density percentage and three photosynthetic pigments, chlorophyll a, b and carotenoids. XiaoMa et al., (2007) on Cynodon dactylon var. Tifway 419 found that treated plants with cycocel at 4 different concentrations reduced plant height and vegetative growth but increased plant density and chlorophyll. They added that the effect was maximized by increasing the applied concentration of cycocel. Also, Golinski et al., (2008) on perennial ryegrass and Ying Chung and Chin Jin (2009) on three bermuda grass varieties, Tifdward, Tifgreen 328 and Tifway 419. They reported that cycocel reduced cutting quantity of these plants.

Therefore, the present trial was planned to cultivate Lolium perenne in different growing media types, namely, clay, sand, sand + clay (2:1) and sand + compost $(2: 1)$ in combination with cycocel or alar at two concentrations 1000 and 2000 ppm.

\section{Materials and Methods}

The present trial was conducted at the Experimental Farm, Fac. Agri., Minia Univ. during two successive seasons, 2008 / 2009 and 2009 / 2010 to investigate the response of ryegrass (Lolium perenne) plants to four growing media types and two growth retardants (cycocel and alar each at 1000 and 2000 ppm).

The field experiment was performed as split plot design, in 4 replicates, where the main plots represented 4 different media types [clay loamy, 
sand, sand + compost (2:1 v/v) and sand +clay loamy $(2: 1 \mathrm{v} / \mathrm{v})]$ and sub plots were 5 growth retardants concentrations (0, 1000 ppm CCC, 2000 ppm CCC, 1000 ppm alar and 2000 ppm alar).

The experimental area was prepared in $1.5 \times 1.0$ $\mathrm{m}$ plots. Such plots were digged out to $30 \mathrm{~cm}$ depth, than refilled with one of the four assigned media types. These media types were prepared and mixed thoroughly before filling the assigned plots. Before planting the seeds, the soil was completely leveled and smoothed. Physical and chemical properties of clay loam, sand and compost are given in tables (a) and (b). The used compost was obtained from the Egyptian Co. for solid waste utilization, new Minia city, and called Nile compost. It is a natural organic plants sugar beet and sugar cane.

Seeds of Lolium perenne were sown by broadcasting method on Nov. $15^{\text {th }}$ and Nov. $18^{\text {th }}$ for the first and second seasons at the rate of $1 \mathrm{~kg} / 25 \mathrm{~m}^{2}$ $\left(60 \mathrm{~g} / 1.5 \mathrm{~m}^{2}\right)$. Irrigation was done promptly daily for one week, then every two days for the second week using a hand sprayer. Then irrigation was applied regularly thereafter.

Table a. Physical and chemical properties of clay loam and sandy soils.

\begin{tabular}{|c|c|c|c|c|c|}
\hline \multirow{2}{*}{\multicolumn{2}{|c|}{ Property }} & \multicolumn{2}{|c|}{ Clay loam } & \multicolumn{2}{|c|}{ Sand } \\
\hline & & $1^{\text {st }}$ & $2^{\text {nd }}$ & $1^{\text {st }}$ & $2^{\text {nd }}$ \\
\hline \multicolumn{2}{|l|}{ Sand \% } & 28.5 & 29.8 & 87.2 & 88.0 \\
\hline \multicolumn{2}{|l|}{ Silt $\%$} & 30.1 & 30.0 & 9.0 & 8.5 \\
\hline \multicolumn{2}{|l|}{ Clay \% } & 41.4 & 40.2 & 3.8 & 3.5 \\
\hline \multicolumn{2}{|l|}{ Soil type } & Clay loam & Clay loam & Sand & Sand \\
\hline \multicolumn{2}{|c|}{ Organic matter \% } & 1.57 & 1.55 & 0.06 & 0.06 \\
\hline \multicolumn{2}{|l|}{ CaCO3 \% } & 2.11 & 2.13 & 8.23 & 8.21 \\
\hline \multicolumn{2}{|l|}{ pH (1:2.5) } & 7.76 & 7.78 & 8.42 & 8.39 \\
\hline \multicolumn{2}{|c|}{ E.C. mmhose / cm } & 1.06 & 1.04 & 1.14 & 1.12 \\
\hline \multicolumn{2}{|l|}{ Total N \% } & 0.08 & 0.08 & 0.017 & 0.015 \\
\hline \multicolumn{2}{|c|}{ Available P \% } & 15.12 & 15.16 & 6.25 & 6.24 \\
\hline \multicolumn{2}{|c|}{ Exch. K mg / 100 g } & 2.16 & 2.13 & 1.42 & 1.33 \\
\hline \multirow{4}{*}{$\begin{array}{c}\text { DTPA } \\
\text { Ext. ppm }\end{array}$} & $\mathbf{F e}$ & 8.51 & 8.48 & 2.18 & 2.16 \\
\hline & $\mathbf{C u}$ & 2.09 & 2.06 & 0.52 & 0.55 \\
\hline & Zn & 2.70 & 2.74 & 0.48 & 0.47 \\
\hline & Mn & 8.18 & 8.14 & 1.35 & 1.34 \\
\hline
\end{tabular}

Table b. Physical and chemical properties of the used compost.

\begin{tabular}{|c|c|c|c|}
\hline Properties & Value & Properties & Value \\
\hline Weight of $1 \mathrm{~m}^{3}$ dry & $450 \mathrm{~kg}$ & Org. carbon \% & $15.7-17.4$ \\
\hline Weight of $1 \mathrm{~m}^{3}$ fresh & $600 \mathrm{~kg}$ & Ash & $55-69$ \\
\hline Moisture $\quad \%$ & 25 & $\mathrm{C} / \mathrm{N}$ ratio & $17.5-1$ \\
\hline pH (1:10) & 8.7 & Total P & 0.45 \\
\hline E.C. mmhose / cm & 2.95 & Total K & 1.29 \\
\hline Total N \% & $0.8-1.2$ & ppm & 6450 \\
\hline Ammonium N ppm & 990 & ppm & 264 \\
\hline Nitrate $\mathbf{N}$ ppm & 283 & ppm & 224 \\
\hline Org. matter & $27-30$ & $\mathrm{ppm}$ & 606 \\
\hline
\end{tabular}

Each of cycocel and alar were applied by hand sprayer 3 times after 20 days from seeding with one month intervals, while control treatment received tap water 3 times also at the same schedule. Misrol, as a sticking agent was used at the rate of $1 \mathrm{~cm} / \mathrm{l}$ for all cycocel and alar treatments. Other agricultural practices were performed regularly as usual.

Three clippings were taken after one month from each growth retardant application. General NPK fertilization was applied at the rate of $7 \mathrm{~g} / 1.5 \mathrm{~m}^{2}$ plot (2:1:1) three times 2 weeks before each clipping. Data were recorded, for vegetative growth, three times for each season:-
1-Plant height $(\mathrm{cm})$ was measured one day before each clipping.

2-Covering density \% was determined by using a wooden quadrate of $10 \times 10 \mathrm{~cm}$ (a gird) divided into 100 squares by cross - string, so that each square represented $1.0 \%$ of the total area of the gird. This gird was dropped at random 6 times for each experimental unit. Then the number of squares occupied by grass was counted and the percentages of covered area were calculated (ElTantawy et al., 1993).

3-Clipping fresh weight (g) for the $1.5 \mathrm{~m}^{2}$ plot immediately after cutting. 
4-Clipping dry weight (g) for the $1.5 \mathrm{~m}^{2}$ plot was determined by air drying then oven dry at $70^{\circ} \mathrm{C}$.

Chlorophyll a, b and carotenoids content (mg/g F. Wt.) were determined in the third clipping for each season according Fadl and Seri-El-Deen (1978).

All obtained data in the two seasons, were statistically analyzed according to L.S.D. method described by Little and Hills (1978).

\section{Results}

\section{A-Vegetative growth characters:}

A-1- Plant height:-

Concerning growing media types, for the three clippings, clay gave the tallest plants, followed by sand + clay, sand + compost and then sand which gave the shortest plants in the two seasons, In the first clipping, plant height was decreased by 13.2, 28.3 and $41.5 \%$ for sand / clay, sand / compost and in comparison with clay soil, respectively, in the first season. The corresponding reduction in the second season were $13.1,27.8$ and $41.3 \%$, respectively as shown in Table (1). The same trend was observed for the second and third clippings (Tables 2 and 3). The role of compost, as well as, other organic materials as amendments, in improving sand or humble soils capability in augmenting plant height of Lolium perenne was revealed by many authors. Examples are Barker (2001), Sellers et al., (2002) and Scherer (2004).

In regard to the effect of the two examined growth retardants, cycocel and alar on plant height of Lolium perenne was consistently reduced due to the use of cycocel or alar comparing to that of untreated plants (Tables 1, 2 and 3). Within each growth retardant, the high concentration (2000 ppm) was more effective than the low one (1000 ppm). In addition, alar at either concentration was more efficient in reducing plant height than the corresponding ones of cycocel. Among the three clippings, plant height exposed to the maximum reduction in the third clipping, followed by the second clipping and then the first clipping. The numerical reduction in plant height, for the first clipping, reached 10.7 and $21.4 \%$ in the first season and 13.5 and $26.5 \%$ in the second one, respectively due to cycocel at $2000 \mathrm{ppm}$ and alar at $2000 \mathrm{ppm}$ in comparison with control plant. Tables (2 and 3) express the same trend of shortening plant height, for the second and then third clipping in both seasons, due to the use of cycocel and alar, with the greatest reduction resulted from alar at $2000 \mathrm{ppm}$ (25.1 and $28.8 \%$ for the second clipping and 26.5 and $31.9 \%$ for the third clipping, in the two seasons, respectively , in comparison to untreated plants). Similar results were obtained by Soliman (1997) on Lolium perenne and Manoly (2000) on bermuda grass.

The interaction between growing media types and growth retardants for plant height was not significant, in both seasons for the three clippings as shown in Tables (1, 2 and 3).

\section{A-2- Covering density percentage:}

Covering density \% came to the maximum values, in the two seasons, for the third clipping (55.7 $\%$ in the first season and $58.4 \%$ in the second one), followed by the second clipping (51.6\% and 55.9 $\%)$, then the first clipping which gave the lowest values (46.8 and $51.7 \%$, respectively) as illustrated in Tables (4.5 and 6). Within each clipping and for both seasons, clay soil gave significantly the highest covering density \% , followed by sand / clay, then sand / compost, while plain sandy soil gave the lowest covering \% (Tables 4, 5 and 6). A good number of researches concluded that incorporating organic materials with sandy soil improves such type of soils in terms of enhancing covering density \% of Lolium perenne (Sorochan and Rogers, 2001 ; Sellers et al., 2002 and Scherer, 2004).

All of the four growth retardant treatments caused a significant increase in covering density \% over the control plants for the three clippings in both first and second seasons. Among the four growth retardant treatments, alar at $2000 \mathrm{ppm}$ was superior to the other treatments, in both seasons for the three clippings, in giving the highest \% of covering density (Tables 4, 5 and 6). Similar results were obtained by Giolinski et al., (2008) on Lolium perenne regarding cycocel, while Manoly (2000) and Xiaoma et al., (2007) emphasized the effectiveness of alar in promoting covering density \% of Cynodon dactylon plants.

The interaction between growing media types and growth retardant treatments was significant in the second season for both second and third clippings. It is interesting to find out that growing Lolium perenne in sand / compost with the supplement of alar at 2000 ppm resulted in covering density \% much better than that obtained from clay or sand / clay with or without the supplement of cycocel at 1000 or $2000 \mathrm{ppm}$ as shown in Table (6).

\section{A-3-Clipping fresh and dry weights :}

Tables $(7,8,9,10,11$ and 12) indicated that both fresh and dry weights of clipping were gradually decreased downward from the first clipping to the second and then the third clipping. The heaviest fresh and dry weights were obtained from clay soil, sand / clay, sand / compost and then sand soil for the three clippings during first and second seasons. In accordance with these results were those obtained by Soumare et al., (2003a) and Soumare et al., (2003b) on Lolium perenne.

All four used growth retardant treatments gave significantly lower clipping fresh and dry weights for the first, second and third clippings in both seasons in comparison with that of untreated plants. The most effective treatment in minimizing clipping fresh and dry weights in the two seasons was alar 2000 ppm. While, control treatment gave the heaviest fresh and dry weights. In agreement with our results 
concerning cycocel were the findings of Soliman (1997) and Golinski et al., (2008) on Lolium perenne. Meanwhile, the reducing effect of alar on fresh and dry weights of turf grass were revealed by Manoly (2000) and XiaoMa et al., (2007) on bermuda grass.

The interaction between growing media and growth retardant treatments for clipping fresh and dry weights was significant for the three clippings except, that of the first season, in the second clipping for fresh weight and first clipping for dry weight (Tables 7, 8, 9, 10, 11 and 12). It seems that growing Lolium perenne turf grass in sandy soil amended with compost $(2: 1 \mathrm{v} / \mathrm{v})$ along with alar $2000 \mathrm{ppm}$ minimized to a great extend, the fresh and dry weights of each one of the three clippings.

B- Chemical constituents:-

Photosynthetic pigments:-

Tables (13, 14 and 15) show that clay soil gave significantly the highest chlorophyll a, b and carotenoids contents over the three tested soil media types, namely sand, sand / compost sand / clay. It is obvious that sandy soil gave the least values, while the two mixed soil types, sand / compost and sand / clay gave intermediate values. These results proved to be true in the two seasons. In close agreement with these results were those revealed by Lawson (2002) and Montemurro et al., (2004) on Lolium perenne.

Concerning growth retardant treatments both cycocel and alar at two concentrations each caused increase in chlorophyll a, b and carotenoids contents in both season over that of check plants. Generally, alar growth retardant more effective than cycocel in this concern. The role of alar and cycocel in inducing chlorophyll a, b and carotenoids contents was reported by Manoly (2000) and XiaoMa et al., (2007) on Bermuda grass.

The interaction between growing media types and growth retardant treatments was significant for chlorophyll a, b contents in the two seasons (Tables 13 and 14). The highest chlorophyll a and b content was due to clay / alar 2000 ppm treatment, while, the lowest values were given by sand / free retardant treatment. However, both chlorophyll a and b contents resulted from sand / compost-alar 2000 ppm was not significant differ from the conventional clay treatment.

\section{Discussion}

The lowest values of different studied vegetative growth characters and photosynthetic pigments in both seasons were obtained due to growing Lolium perenne in sandy soil. Such soil is characterized by low and lack of organic matter, lack of major and minor elements for plant nutrition, limited microbial flora, low water holding capacity and cation exchange capacity (Hamdy, 1996). The addition of compost, as an organic amendment, or clay, when added to sandy soil, improves its physical, chemical and biological properties and provide the plants with nutrients (Youssef et al., 2001) increasing its water holding capacity (Aly, 1988). Such great diversity of advantages, due to the addition of compost or clay to sandy soil, aids in improving the growth of Lolium perenne.

The reduction in plant height due to cycocel or alar could be referred to the inhibition of cell division and cell expansion in the subapical meristems (Wilde and Edgerton, 1969) or due to the retardation of the longitudinal growth of their cells (Lee and Lee, 1991). It was noticed that the reduction in fresh and dry weights was consistent with that imposed on plant on plant height.

In regard to the promoting influence of cycocel and alar on covering density $\%$, it might be due to the reduced apical control or apical dominance by restricting the growth in apical and sub-apical meristemic tissues, thereby, simultaneous growth of many shoot axes which permit axillary buds, and branching development (Sach and Hackett, 1972). While the increase in the three photosynthetic pigments as shown in the obtained results was in close agreement with the findings of Sach and Hackett (1972) and Cathey (1975) who pointed out that cycocel and alar treated plants had darker green color and high chlorophylls content.

\section{References}

Aly, M.R. (1988): Effect of certain amendments on improving soil fertility and performance in newly reclaimed sandy soil. M Sc. Thesis, Fac. of Agric., Minia Univ.

Barker, A.V. (2001): Evaluation of composts for growth of grass sod. CAB Abstracts, Communications, in Soil Sci. \& Plant Analysis, 2001:32 (11/12) : 1841-1860.

Cathey, H.M. (1975): Comparative plant growth retarding activities of ancymidol with ACPC, phosphon, chlormequat and SADH on ornamental plant species. Hort. Science, Vol. 10 (3), 1975.

El-Tantawy, A.; Hanafy, M.S. and Hossny, Y.A. (1993): Effect of different growing media and sowing dates on growth of Bermuda grass (Cynodon dactylon, L.) Minia J. Agric. Res. \& Dev. (Special Issue) Vol. 15, 1993 : 1079 - 1098.

Fadl, M.S. and Seri-El-Deen, S.A. (1978): Effect of N-benzyladenine on photosynthetic pigments and total soluble sugars of olive seedlings grown under saline condition. Res. Bul. No. 843, Fac. of Agric,. Ain Shams Univ.

Golinski, P.; Joks, W.; Golinska, B. and Puslednik, M. (2008): Efficiency of growth regulators application in seed plantation of perennial ryegrass. Progress in Plant Protection, 2008, 48 (2) : 586 - 589. ISSN.

Hamdy, Y. A. (1996) : Agrotechnologies based on organic matter management and biological nitrogen fixation for desert soils. The National 
Symp. on Nitrogen - fixing Leucaena Trees, ElArish, N. Sinai, Egypt, Dec. 1996.

Khalil, A.A. Nasef, M.A. Ghazal, F.M. and ElEmam, M.A. (2004): Effect of integrated manuring and bio-fertilizer on growth and nutrient uptake of wheat plants grown in diverse textures soils. Egypt J. Agric. Res., 82 (2) : 221 234.

Lawson, D.M. (2002): Compost application to football turf on an unamended soil rootzone. $\mathrm{CAB}$ Abstracts, J. of Turf grass \& Sports Surface Sci., 2002, 78: $71-76$.

Lee, P.O. and Lee, J.S (1991): Effect of ancymidol and paclobutrazol on growth and flowering of potted gerbera. J. of The Korean Soc. For Hort. Sci. 31 (93) : $300-304$.

Little, J.M. and Hills, F.J. (1978): Agricultural Experimentations Design and Analysis. Jon Wiley \& sons Inc. New York, U.S.A.

Manoly, N.D. (2000): Effect of fertilization and growth retardants on growth of Bermuda grass (Cynodon dactylon, L.) Egypt J. Appl. Sci., 15(12) : $730-745$.

Montemurro, F.; Convertini, G. and Ferri, D. (2004): Mill wastewater and olive pomace compost as amendments for ryegrass. CAB Abstracts. Agronomie, 2004; 24(8): 481 - 486.

Sachs, R.M. and Hackett, W.P. (1972): Chemical inhibition of plant height. Hort. Science, Vol. 7(5): 1972.

Scherer, H.W. (2004): Influence of compost application on growth and phosphorus exploitation of ryegrass (Lolium perenne, L.) CAB Abstract, Plant, Soil AND environment, 2004, 50 (12): 518 - 524.

Schnell, R.W.; Vietor, D.W.; White, R.H.; Provin, T.L. and Manster, C.L. (2009): Effect of composted bio-solids and nitrogen on turf grass establishment, sod properties and nutrient export at harvest. Hort. Science, 2009 44(6): 1746 1750 .

Seller, G.; McRae, S.G. and Cook, H.F. (2002): Ryegrass, Fescue and clover growth on London
Clay amended with waste material. CAB Abstracts. Land contamination \& Reclamation, 2002, 10(2): $79-89$.

Soliman, M.A. (1997): Studies on some turf grass plants. M. Sc. Thesis, Fac. of Agric. Kafr Elsheikh, Tanta Univ.

Sorochan, J.C. and Rogers, J.N. (2001): The effect of mulch type for turf grass establishment within a refined wood fiber mat over plastic. CAB Abstracts, J. of Env. Hort. 2001, 19(2): 61 - 64.

Soumare, M.; Tack, F.M. and Verloo, M.G. (2003a): Effect of a municipal solid waste compost and mineral fertilization on plant growth in two tropical agricultural solids of Mali. CAB Abstracts, Biosource Technology, 2003; 86(1): 15 -20 .

Soumare, M.; Tack, F.M. and Verloo, M.G. (2003b): Ryegrass response to mineral fertilization and organic amendment with municipal solid waste compost in two tropical agricultural solids in Mali. CAB Abstracts, J. of Plants Nutrition, 2003, 26(6): 1169 - 1188

Wilde, M.H. and Edgerton, L.J. (1969): Some effects of growth retardant on shoot meridtems of apple. J. Amer. Soc. Hort. Scio., 94: 118 - 122.

Williamson, J.F. (1975): Sunset Western Gradern Book. 13 ${ }^{\text {th }}$ Printing, Land Magazine \& Book Company, Menlo Park, Calif., U.S.A.

Ying Chung, C. and ChinJin, H. (2009): Effect of plant growth regulatoers on the growth and vegetation color of Bermuda grass Crop, Environment \& Bioinformatics. 2009, 6(1): 1-14, ISSN.

Youssef, A.M.; El-Fouly, A.H.; Youssef, M.S. and Mohamedien, S.A. (2001): Effect of using organic and chemical fertilizers in fertigation system on yield and fruit quality of tomato. Egypt J. Hort., 28: $59-77$.

XiaoMa, J.; Rukian, Y.; Qing, Y. and Yanxiang, H. (2007): Effect of plant growth retardants on growing characteristics of turf grass Cynodon dactylon. Pratacultural Science, 2007, 24(6): 90 95. ISSN.

Table 1. Effect of growing media types and growth retardants on plant height $(\mathrm{cm})$ before the first clipping of Lolium perenne, L. during 2008/2009 and 2009/2010.

\begin{tabular}{|c|c|c|c|c|c|c|c|c|c|c|c|c|}
\hline \multirow{3}{*}{$\begin{array}{c}\text { Growing } \\
\text { media types } \\
\text { Growth } \\
\text { retardant } \\
\text { concentrations } \\
\text { (ppm) }\end{array}$} & \multicolumn{12}{|c|}{ Plant height $(\mathrm{cm})$ before the first clipping } \\
\hline & \multicolumn{8}{|c|}{ First season } & \multicolumn{4}{|c|}{ Second season } \\
\hline & $\begin{array}{c}\text { Control } \\
\mathbf{0}\end{array}$ & $\begin{array}{l}\text { CCC } \\
1000\end{array}$ & $\begin{array}{l}\text { CCC } \\
2000\end{array}$ & $\begin{array}{l}\text { Alar } \\
1000\end{array}$ & $\begin{array}{l}\text { Alar } \\
2000\end{array}$ & $\begin{array}{c}\text { Mean } \\
\text { A }\end{array}$ & $\begin{array}{c}\text { Control } \\
0\end{array}$ & $\begin{array}{l}\text { CCC } \\
1000\end{array}$ & $\begin{array}{l}\text { CCC } \\
2000\end{array}$ & $\begin{array}{l}\text { Alar } \\
1000\end{array}$ & $\begin{array}{l}\text { Alar } \\
2000\end{array}$ & $\begin{array}{c}\text { Mean } \\
\text { A }\end{array}$ \\
\hline S & 14.2 & 14.0 & 12.1 & 11.3 & 10.2 & 12.4 & 17.7 & 16.9 & 14.6 & 13.1 & 11.7 & 14.8 \\
\hline S + Comp. & 17.3 & 16.2 & 15.3 & 14.2 & 13.1 & 15.2 & 21.2 & 19.7 & 18.2 & 16.6 & 15.2 & 18.2 \\
\hline $\mathbf{S}+\mathbf{C}$ & 20.1 & 20.1 & 18.2 & 17.2 & 16.3 & 18.4 & 24.7 & 24.0 & 21.7 & 20.5 & 18.6 & 21.9 \\
\hline $\mathbf{C}$ & 23.1 & 22.2 & 21.2 & 20.1 & 19.2 & 21.2 & 28.4 & 26.8 & 25.1 & 23.8 & 22.1 & 25.2 \\
\hline Mean B & 18.7 & 18.1 & 16.7 & 15.7 & 14.7 & & 23.0 & 21.9 & 19.9 & 18.5 & 16.9 & \\
\hline $\begin{array}{ll}\text { L.S.D. } & 5 \% \\
\end{array}$ & $\mathbf{A}$ & 1.3 & $\mathbf{B}$ & 2.0 & $\mathbf{A B}$ & N.S. & A & 1.1 & B & 2.1 & $\mathbf{A B}$ & N.S. \\
\hline $1 \%$ & & 1.9 & & 2.7 & & N.S. & & 1.7 & & 2.8 & & N.S. \\
\hline
\end{tabular}

S: Sand Comp.: Compost C : Clay 
Table 2. Effect of growing media types and growth retardants on plant height $(\mathrm{cm})$ before the second clipping of Lolium perenne, L. during 2008/2009 and 2009/2010.

\begin{tabular}{|c|c|c|c|c|c|c|c|c|c|c|c|c|}
\hline \multirow{3}{*}{$\begin{array}{l}\text { Growing } \\
\text { media types } \\
\text { Growth } \\
\text { retardant } \\
\text { concentrations } \\
\text { (ppm) }\end{array}$} & \multicolumn{12}{|c|}{ Plant height (cm) before the second clipping } \\
\hline & \multicolumn{8}{|c|}{ First season } & \multicolumn{4}{|c|}{ Second season } \\
\hline & $\begin{array}{c}\text { Control } \\
0\end{array}$ & $\begin{array}{l}\text { CCC } \\
1000\end{array}$ & $\begin{array}{l}\text { CCC } \\
2000\end{array}$ & $\begin{array}{l}\text { Alar } \\
1000\end{array}$ & $\begin{array}{l}\text { Alar } \\
2000\end{array}$ & $\begin{array}{c}\text { Mean } \\
\text { A }\end{array}$ & $\begin{array}{c}\text { Control } \\
0\end{array}$ & $\begin{array}{l}\text { CCC } \\
1000\end{array}$ & $\begin{array}{l}\text { CCC } \\
2000\end{array}$ & $\begin{array}{l}\text { Alar } \\
1000\end{array}$ & $\begin{array}{l}\text { Alar } \\
2000\end{array}$ & $\begin{array}{c}\text { Mean } \\
\text { A }\end{array}$ \\
\hline $\mathbf{S}$ & 13.3 & 12.3 & 11.2 & 10.1 & 8.7 & 11.1 & 16.2 & 14.6 & 13.3 & 11.7 & 10.1 & 13.2 \\
\hline S + Comp. & 15.4 & 14.2 & 13.2 & 11.4 & 11.1 & 13.1 & 18.7 & 17.1 & 15.9 & 13.5 & 12.7 & 15.6 \\
\hline $\mathbf{S}+\mathbf{C}$ & 18.4 & 17.2 & 16.1 & 15.1 & 14.0 & 16.2 & 22.4 & 19.9 & 19.3 & 17.6 & 16.3 & 19.1 \\
\hline C & 21.4 & 20.3 & 19.0 & 18.1 & 17.4 & 19.0 & 25.7 & 24.1 & 22.7 & 21.3 & 19.9 & 22.7 \\
\hline Mean B & 17.1 & 16.0 & 14.9 & 13.7 & 12.8 & & 20.8 & 18.9 & 17.8 & 16.0 & 14.8 & \\
\hline L.S.D. $5 \%$ & A & 1.1 & B & 1.6 & AB & N.S. & A & 1.7 & B & 2.6 & AB & N.S. \\
\hline $1 \%$ & & 1.7 & & 2.2 & & N.S. & & 2.5 & & 3.6 & & N.S. \\
\hline \multicolumn{13}{|c|}{ S: Sand } \\
\hline
\end{tabular}

Table 3. Effect of growing media types and growth retardants on plant height $(\mathrm{cm})$ before the third clipping of Lolium perenne, L. during 2008/2009 and 2009/2010.

\begin{tabular}{|c|c|c|c|c|c|c|c|c|c|c|c|c|}
\hline \multirow{3}{*}{$\begin{array}{l}\text { Growing } \\
\text { media types } \\
\text { Growth } \\
\text { retardant } \\
\text { concentrations } \\
\text { (ppm) }\end{array}$} & \multicolumn{12}{|c|}{ Plant height $(\mathrm{cm})$ before the third clipping } \\
\hline & \multicolumn{8}{|c|}{ First season } & \multicolumn{4}{|c|}{ Second season } \\
\hline & $\begin{array}{c}\text { Control } \\
0\end{array}$ & $\begin{array}{l}\text { CCC } \\
1000\end{array}$ & $\begin{array}{l}\text { CCC } \\
2000\end{array}$ & $\begin{array}{l}\text { Alar } \\
1000\end{array}$ & $\begin{array}{l}\text { Alar } \\
2000\end{array}$ & $\begin{array}{c}\text { Mean } \\
\text { A }\end{array}$ & $\begin{array}{c}\text { Control } \\
\mathbf{0}\end{array}$ & $\begin{array}{l}\text { CCC } \\
1000\end{array}$ & $\begin{array}{l}\text { CCC } \\
2000\end{array}$ & $\begin{array}{l}\text { Alar } \\
1000\end{array}$ & $\begin{array}{l}\text { Alar } \\
2000\end{array}$ & $\begin{array}{c}\text { Mean } \\
\text { A }\end{array}$ \\
\hline $\mathbf{S}$ & 12.0 & 11.2 & 10.2 & 9.2 & 8.1 & 10.1 & 14.7 & 13.2 & 11.8 & 10.1 & 9.0 & 11.8 \\
\hline S + Comp. & 13.1 & 12.1 & 11.2 & 10.1 & 9.2 & 11.1 & 16.8 & 15.2 & 14.1 & 12.2 & 10.7 & 13.8 \\
\hline $\mathrm{S}+\mathrm{C}$ & 16.0 & 15.4 & 14.1 & 13.2 & 12.1 & 14.2 & 20.3 & 18.7 & 17.2 & 15.6 & 14.0 & 17.2 \\
\hline C & 19.2 & 18.3 & 17.0 & 16.9 & 15.1 & 17.3 & 23.7 & 22.4 & 20.6 & 19.9 & 17.6 & 20.8 \\
\hline Mean B & 15.1 & 14.3 & 13.1 & 12.4 & 11.1 & & 18.8 & 17.4 & 15.9 & 14.5 & 12.8 & \\
\hline L.S.D. $5 \%$ & A & 1.3 & B & 1.8 & AB & N.S. & A & 0.9 & B & 2.0 & AB & \\
\hline $1 \%$ & & 1.9 & & 2.5 & & N.S. & & 1.4 & & 2.7 & & \\
\hline \multicolumn{13}{|c|}{ S: Sand } \\
\hline
\end{tabular}

Table 4. Effect of growing media types and growth retardants covering density \% after the first clipping of Lolium perenne, L. during 2008/2009 and 2009/2010.

\begin{tabular}{|c|c|c|c|c|c|c|c|c|c|c|c|c|}
\hline \multirow{3}{*}{$\begin{array}{l}\text { Growing } \\
\text { media types } \\
\text { Growth } \\
\text { retardant } \\
\text { concentrations } \\
\text { (ppm) }\end{array}$} & \multicolumn{12}{|c|}{ Covering density \% after the first clipping } \\
\hline & \multicolumn{8}{|c|}{ First season } & \multicolumn{4}{|c|}{ Second season } \\
\hline & $\begin{array}{c}\text { Control } \\
0\end{array}$ & $\begin{array}{l}\text { CCC } \\
1000\end{array}$ & $\begin{array}{l}\text { CCC } \\
2000\end{array}$ & $\begin{array}{l}\text { Alar } \\
1000\end{array}$ & $\begin{array}{l}\text { Alar } \\
2000\end{array}$ & $\begin{array}{c}\text { Mean } \\
\text { A }\end{array}$ & $\begin{array}{c}\text { Control } \\
0\end{array}$ & $\begin{array}{l}\text { CCC } \\
1000\end{array}$ & $\begin{array}{l}\text { CCC } \\
2000\end{array}$ & $\begin{array}{l}\text { Alar } \\
1000\end{array}$ & $\begin{array}{l}\text { Alar } \\
2000\end{array}$ & $\begin{array}{c}\text { Mean } \\
\text { A }\end{array}$ \\
\hline $\mathbf{S}$ & 26.4 & 29.6 & 32.4 & 37.3 & 44.5 & 34.0 & 31.7 & 34.9 & 37.7 & 42.6 & 49.8 & 39.3 \\
\hline S + Comp. & 32.6 & 36.6 & 42.5 & 50.0 & 58.1 & 43.8 & 37.8 & 41.8 & 47.7 & 55.2 & 61.6 & 48.8 \\
\hline $\mathbf{S}+\mathbf{C}$ & 40.8 & 44.2 & 47.1 & 56.1 & 62.2 & 50.1 & 46.1 & 49.5 & 52.4 & 61.4 & 67.5 & 55.4 \\
\hline C & 47.5 & 54.0 & 58.8 & 65.5 & 70.5 & 59.3 & 52.7 & 59.2 & 64.0 & 66.0 & 74.1 & 63.2 \\
\hline Mean B & 36.8 & 41.1 & 45.2 & 52.2 & 58.8 & & 42.1 & 46.4 & 50.5 & 56.3 & 63.3 & \\
\hline L.S.D. $5 \%$ & A & 2.0 & B & 2.2 & $\mathbf{A B}$ & N.S. & A & 2.1 & B & 2.5 & AB & N.S. \\
\hline $1 \%$ & & 3.0 & & 3.0 & & N.S. & & 3.1 & & 3.4 & & N.S. \\
\hline \multicolumn{13}{|c|}{ S: Sand } \\
\hline
\end{tabular}


Table 5. Effect of growing media types and growth retardants on covering density \% after the second clipping of Lolium perenne, L. during 2008/2009 and 2009/2010.

\begin{tabular}{|c|c|c|c|c|c|c|c|c|c|c|c|c|}
\hline \multirow{3}{*}{$\begin{array}{l}\text { Growing } \\
\text { media types } \\
\text { Growth } \\
\text { retardant } \\
\text { concentrations } \\
\text { (ppm) }\end{array}$} & \multicolumn{12}{|c|}{ Covering density $\%$ after the second clipping } \\
\hline & \multicolumn{6}{|c|}{ First season } & \multicolumn{6}{|c|}{ Second season } \\
\hline & $\begin{array}{c}\text { Control } \\
0\end{array}$ & $\begin{array}{l}\text { CCC } \\
1000\end{array}$ & $\begin{array}{l}\text { CCC } \\
2000\end{array}$ & $\begin{array}{l}\text { Alar } \\
1000\end{array}$ & $\begin{array}{l}\text { Alar } \\
2000\end{array}$ & $\begin{array}{c}\text { Mean } \\
\text { A }\end{array}$ & $\begin{array}{c}\text { Control } \\
0\end{array}$ & $\begin{array}{l}\text { CCC } \\
1000\end{array}$ & $\begin{array}{l}\text { CCC } \\
2000\end{array}$ & $\begin{array}{l}\text { Alar } \\
1000\end{array}$ & $\begin{array}{l}\text { Alar } \\
2000\end{array}$ & $\begin{array}{c}\text { Mean } \\
\text { A }\end{array}$ \\
\hline $\mathbf{S}$ & 31.3 & 34.5 & 37.3 & 42.2 & 49.4 & 38.9 & 34.8 & 38.0 & 40.8 & 45.7 & 52.9 & 42.4 \\
\hline S + Comp. & 37.4 & 41.4 & 47.3 & 54.8 & 59.3 & 48.0 & 40.9 & 44.9 & 50.8 & 58.3 & 74.7 & 53.9 \\
\hline $\mathbf{S}+\mathbf{C}$ & 45.7 & 49.1 & 52.0 & 61.0 & 67.1 & 55.0 & 49.2 & 52.6 & 55.5 & 64.5 & 70.6 & 58.5 \\
\hline C & 52.3 & 58.8 & 63.6 & 70.3 & 76.8 & 64.4 & 55.8 & 62.3 & 67.1 & 73.8 & 83.8 & 68.6 \\
\hline Mean B & 41.7 & 46.0 & 50.1 & 57.1 & 63.2 & & 54.2 & 49.5 & 53.5 & 60.6 & 70.5 & \\
\hline L.S.D. $\quad 5 \%$ & A & 1.8 & B & 2.5 & AB & N.S. & A & 2.3 & B & 2.5 & AB & 4.9 \\
\hline $1 \%$ & & 2.8 & & 3.3 & & N.S. & & 3.5 & & 3.3 & & 6.6 \\
\hline \multicolumn{13}{|c|}{ S: Sand } \\
\hline
\end{tabular}

Table 6. Effect of growing media types and growth retardants on covering density \% after the third clipping of Lolium perenne, L. during 2008/2009 and 2009/2010.

\begin{tabular}{|c|c|c|c|c|c|c|c|c|c|c|c|c|}
\hline \multirow{2}{*}{$\begin{array}{l}\text { Growing } \\
\text { media types } \\
\text { Growth } \\
\text { retardant } \\
\text { concentrations } \\
\text { (ppm) }\end{array}$} & \multicolumn{12}{|c|}{ Covering density $\%$ after the third clipping } \\
\hline & $\begin{array}{c}\text { Control } \\
0\end{array}$ & $\begin{array}{l}\text { CCC } \\
1000\end{array}$ & $\begin{array}{l}\text { CCC } \\
2000\end{array}$ & \multirow{2}{*}{$\begin{array}{l}\text { Alar } \\
\mathbf{1 0 0 0} \\
46.4\end{array}$} & \multirow{2}{*}{$\begin{array}{l}\text { Alar } \\
\mathbf{2 0 0 0}\end{array}$} & \multirow{2}{*}{$\begin{array}{c}\text { Mean } \\
\text { A }\end{array}$} & \multirow{2}{*}{$\begin{array}{c}\begin{array}{c}\text { Control } \\
\mathbf{0}\end{array} \\
37.3\end{array}$} & \multirow{2}{*}{$\begin{array}{l}\text { CCC } \\
1000 \\
40.5\end{array}$} & \multirow{2}{*}{$\begin{array}{l}\text { CCC } \\
\mathbf{2 0 0 0} \\
43.3\end{array}$} & \multirow{2}{*}{$\begin{array}{l}\text { Alar } \\
\mathbf{1 0 0 0} \\
48.2\end{array}$} & \multirow{2}{*}{$\begin{array}{l}\text { Alar } \\
\mathbf{2 0 0 0}\end{array}$} & $\begin{array}{c}\text { Mean } \\
\text { A }\end{array}$ \\
\hline $\mathrm{S}$ & 35.5 & 38.7 & 41.5 & & & & & & & & & 44.9 \\
\hline S + Comp. & 41.6 & 45.6 & 51.5 & 59.0 & 70.8 & 53.7 & 43.4 & 47.4 & 53.3 & 60.8 & 77.2 & 56.4 \\
\hline $\mathbf{S}+\mathbf{C}$ & 49.9 & 53.3 & 56.2 & 65.2 & 71.3 & 59.2 & 51.7 & 55.1 & 58.0 & 67.0 & 73.1 & 61.0 \\
\hline C & 56.5 & 63.0 & 67.8 & 69.8 & 76.9 & 66.8 & 58.3 & 64.8 & 69.6 & 76.3 & 86.3 & 71.1 \\
\hline Mean B & 45.9 & 50.2 & 54.3 & 60.1 & 68.2 & & 47.7 & 52.0 & 56.1 & 63.1 & 73.0 & \\
\hline $\begin{array}{ll}\text { L.S.D. } & 5 \%\end{array}$ & A & 2.0 & B & 2.6 & AB & N.S. & A & 2.9 & B & 2.5 & AB & 5.0 \\
\hline $1 \%$ & & 3.0 & & 3.4 & & N.S. & & 4.4 & & 3.7 & & 7.4 \\
\hline & & & & ua & $\mathbf{P} \cdot$ & ompos & C. & & & & & \\
\hline
\end{tabular}

Table7. Effect of growing media types and growth retardants on fresh weight $\left(\mathrm{g} / 1.5 \mathrm{~m}^{2}\right.$ plot) of the first clipping of Lolium perenne, L. during 2008/2009 and 2009/2010.

\begin{tabular}{|c|c|c|c|c|c|c|c|c|c|c|c|c|}
\hline \multirow{3}{*}{$\begin{array}{l}\text { Growing } \\
\text { media types } \\
\text { Growth } \\
\text { retardant } \\
\text { concentrations } \\
\text { (ppm) }\end{array}$} & \multicolumn{12}{|c|}{ Fresh weight (g/1.5 $\mathrm{m}^{2}$ plot) of the first clipping } \\
\hline & \multicolumn{8}{|c|}{ First season } & \multicolumn{4}{|c|}{ Second season } \\
\hline & $\begin{array}{c}\text { Control } \\
\mathbf{0}\end{array}$ & $\begin{array}{l}\text { CCC } \\
1000\end{array}$ & $\begin{array}{l}\text { CCC } \\
2000\end{array}$ & $\begin{array}{l}\text { Alar } \\
1000\end{array}$ & $\begin{array}{l}\text { Alar } \\
2000\end{array}$ & $\begin{array}{c}\text { Mean } \\
\text { A }\end{array}$ & $\begin{array}{c}\text { Control } \\
\mathbf{0}\end{array}$ & $\begin{array}{l}\text { CCC } \\
1000\end{array}$ & $\begin{array}{l}\text { CCC } \\
2000\end{array}$ & $\begin{array}{l}\text { Alar } \\
1000\end{array}$ & $\begin{array}{l}\text { Alar } \\
2000\end{array}$ & $\begin{array}{c}\text { Mean } \\
\text { A }\end{array}$ \\
\hline $\mathbf{S}$ & 367.7 & 305.6 & 273.3 & 197.4 & 174.0 & 263.6 & 511.4 & 416.2 & 332.5 & 256.4 & 208.9 & 345.1 \\
\hline S + Comp. & 460.7 & 398.5 & 361.5 & 332.0 & 320.9 & 374.7 & 594.4 & 506.7 & 433.6 & 378.5 & 346.4 & 451.9 \\
\hline $\mathbf{S}+\mathbf{C}$ & 531.3 & 505.5 & 445.0 & 452.6 & 423.3 & 471.5 & 657.2 & 598.2 & 510.0 & 480.7 & 436.2 & 536.5 \\
\hline C & 601.3 & 550.3 & 524.0 & 493.1 & 473.8 & 528.5 & 714.0 & 634.7 & 558.9 & 497.6 & 454.7 & 572.0 \\
\hline Mean B & 490.3 & 440.0 & 401.0 & 368.8 & 348.0 & & 619.3 & 539.0 & 458.8 & 403.3 & 361.6 & \\
\hline L.S.D. $\quad 5 \%$ & A & 17.3 & B & 24.1 & AB & 48.2 & A & 18.6 & B & 37.6 & AB & 75.2 \\
\hline $1 \%$ & & 26.2 & & 32.4 & & 64.8 & & 28.2 & & 50.6 & & 101.2 \\
\hline
\end{tabular}


Table 8. Effect of growing media types and growth retardants on fresh weight (g/1.5 $\mathrm{m}^{2}$ plot) of the second clipping of Lolium perenne, L. during 2008/2009 and 2009/2010.

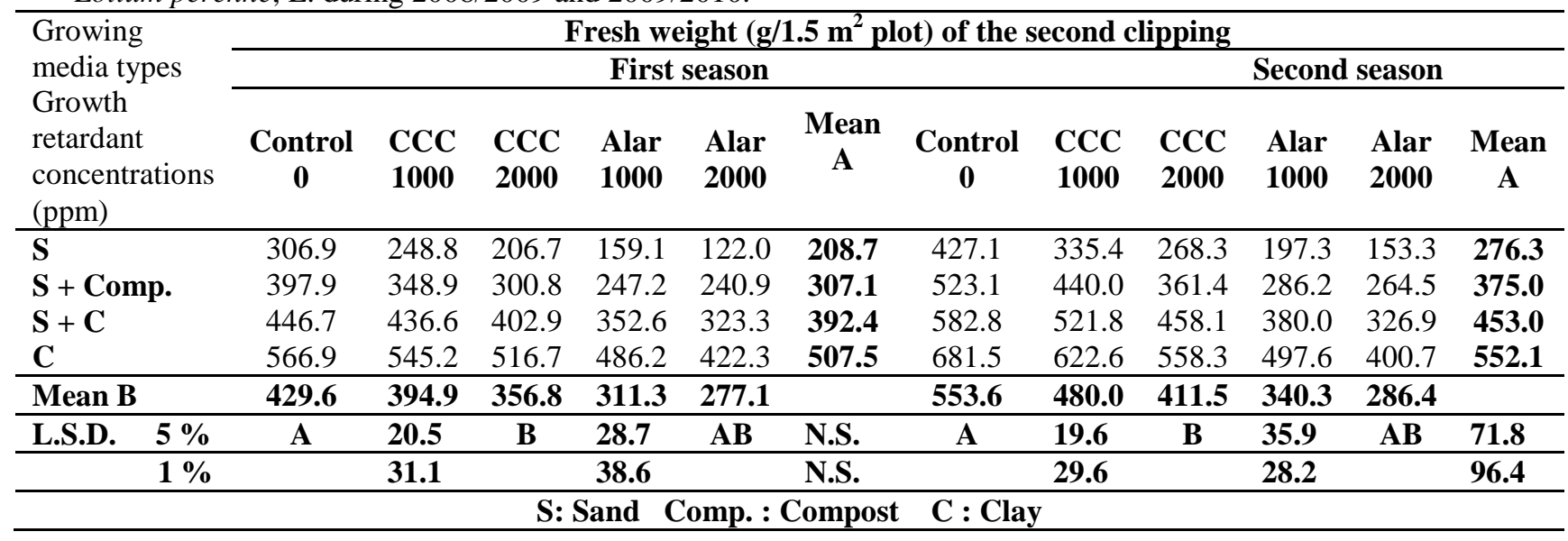

Table 9. Effect of growing media types and growth retardants on fresh weight (g/1.5 $\left.\mathrm{m}^{2} \mathrm{plot}\right)$ of the third clipping of Lolium perenne, L. during 2008/2009 and 2009/2010.

\begin{tabular}{|c|c|c|c|c|c|c|c|c|c|c|c|c|}
\hline \multirow{3}{*}{$\begin{array}{l}\text { Growing } \\
\text { media types } \\
\text { Growth } \\
\text { retardant } \\
\text { concentrations } \\
\text { (ppm) }\end{array}$} & \multicolumn{12}{|c|}{ Fresh weight (g/1.5 $\mathrm{m}^{2}$ plot) of the third clipping } \\
\hline & \multicolumn{8}{|c|}{ First season } & \multicolumn{4}{|c|}{ Second season } \\
\hline & $\begin{array}{c}\text { Control } \\
\mathbf{0}\end{array}$ & $\begin{array}{l}\text { CCC } \\
1000\end{array}$ & $\begin{array}{l}\text { CCC } \\
2000\end{array}$ & $\begin{array}{l}\text { Alar } \\
1000\end{array}$ & $\begin{array}{l}\text { Alar } \\
2000\end{array}$ & $\begin{array}{c}\text { Mean } \\
\text { A }\end{array}$ & $\begin{array}{c}\text { Control } \\
\mathbf{0}\end{array}$ & $\begin{array}{l}\text { CCC } \\
1000\end{array}$ & $\begin{array}{l}\text { CCC } \\
2000\end{array}$ & $\begin{array}{l}\text { Alar } \\
1000\end{array}$ & $\begin{array}{l}\text { Alar } \\
2000\end{array}$ & $\begin{array}{c}\text { Mean } \\
\text { A }\end{array}$ \\
\hline $\mathbf{S}$ & 240.0 & 193.6 & 191.7 & 136.5 & 99.0 & 172.2 & 333.6 & 260.7 & 228.3 & 171.8 & 115.6 & 222.0 \\
\hline S + Comp. & 339.3 & 301.5 & 240.0 & 207.2 & 149.1 & 247.4 & 446.3 & 327.3 & 288.6 & 237.7 & 169.1 & 293.8 \\
\hline $\mathbf{S}+\mathbf{C}$ & 404.0 & 372.4 & 339.3 & 306.7 & 290.8 & 342.6 & 505.6 & 445.9 & 386.9 & 331.3 & 295.4 & 393.0 \\
\hline C & 524.4 & 484.5 & 454.0 & 422.1 & 378.5 & 452.7 & 629.5 & 553.2 & 491.7 & 432.4 & 383.3 & 498.0 \\
\hline Mean B & 376.9 & 338.0 & 306.3 & 268.1 & 229.4 & & 478.8 & 396.8 & 348.9 & 293.3 & 240.9 & \\
\hline L.S.D. & A & 20.4 & B & 23.5 & AB & 47.0 & A & 26.0 & B & 26.3 & AB & 52.6 \\
\hline $1 \%$ & & 30.9 & & 31.6 & & 63.2 & & 39.4 & & 35.4 & & 70.8 \\
\hline \multicolumn{13}{|c|}{ S: Sand } \\
\hline
\end{tabular}

Table 10. Effect of growing media types and growth retardants on dry weight $\left(\mathrm{g} / 1.5 \mathrm{~m}^{2}\right.$ plot) of the first clipping of Lolium perenne, L. during 2008/2009 and 2009/2010.

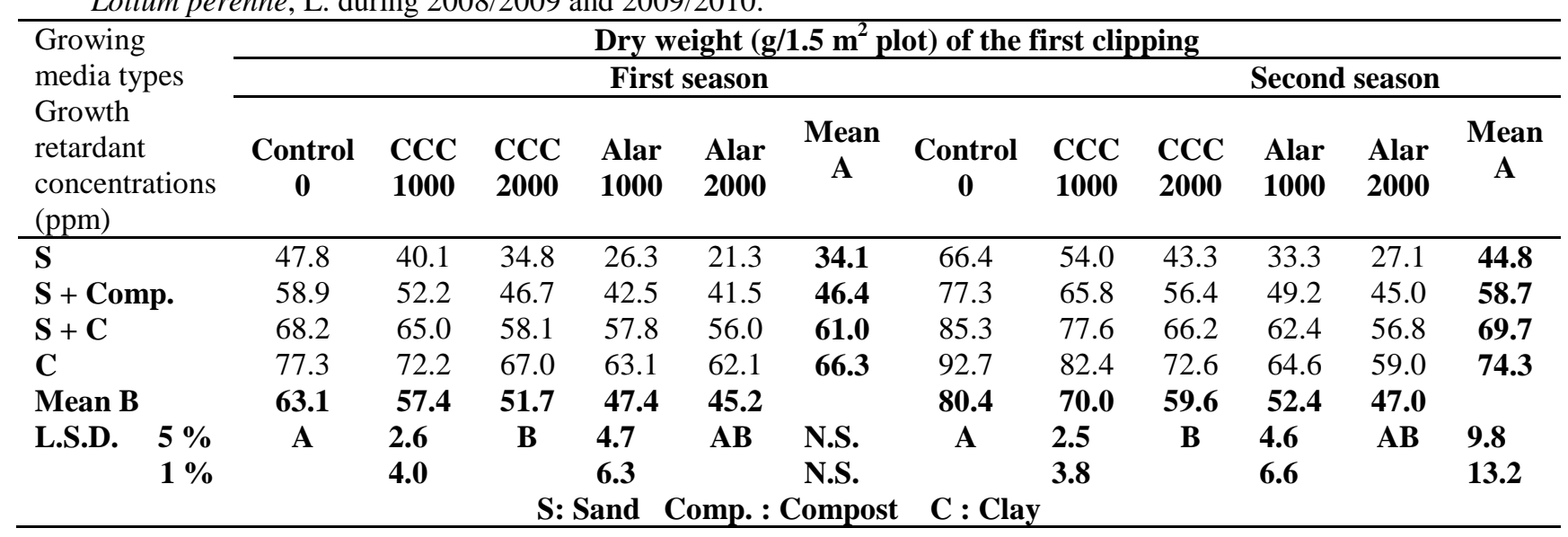


Table 11. Effect of growing media types and growth retardants on dry weight (g/1.5 $\mathrm{m}^{2}$ plot) of the second clipping of Lolium perenne, L. during 2008/2009 and 2009/2010.

\begin{tabular}{|c|c|c|c|c|c|c|c|c|c|c|c|c|}
\hline \multirow{3}{*}{$\begin{array}{l}\text { Growing } \\
\text { media types } \\
\text { Growth } \\
\text { retardant } \\
\text { concentrations } \\
\text { (ppm) }\end{array}$} & \multicolumn{12}{|c|}{ Dry weight (g/1.5 $\mathrm{m}^{2}$ plot) of the second clipping } \\
\hline & \multicolumn{8}{|c|}{ First season } & \multicolumn{4}{|c|}{ Second season } \\
\hline & $\begin{array}{c}\text { Control } \\
0\end{array}$ & $\begin{array}{l}\text { CCC } \\
1000\end{array}$ & $\begin{array}{l}\text { CCC } \\
2000\end{array}$ & $\begin{array}{l}\text { Alar } \\
1000\end{array}$ & $\begin{array}{l}\text { Alar } \\
2000\end{array}$ & $\begin{array}{c}\text { Mean } \\
\text { A }\end{array}$ & $\begin{array}{c}\text { Control } \\
0\end{array}$ & $\begin{array}{l}\text { CCC } \\
1000\end{array}$ & $\begin{array}{l}\text { CCC } \\
2000\end{array}$ & $\begin{array}{l}\text { Alar } \\
1000\end{array}$ & $\begin{array}{l}\text { Alar } \\
2000\end{array}$ & $\begin{array}{c}\text { Mean } \\
\text { A }\end{array}$ \\
\hline $\mathbf{S}$ & 39.9 & 32.4 & 26.8 & 20.6 & 15.9 & 27.1 & 55.5 & 43.6 & 34.8 & 25.6 & 20.0 & 35.9 \\
\hline S + Comp. & 51.6 & 45.3 & 39.0 & 32.2 & 31.4 & 39.9 & 67.9 & 57.2 & 46.9 & 37.2 & 34.4 & 48.7 \\
\hline $\mathbf{S}+\mathbf{C}$ & 59.1 & 54.7 & 52.3 & 45.8 & 42.0 & 50.8 & 75.7 & 67.8 & 59.4 & 49.4 & 42.5 & 59.0 \\
\hline $\mathbf{C}$ & 73.7 & 70.8 & 67.1 & 63.1 & 54.9 & 65.9 & 88.5 & 80.8 & 72.5 & 64.6 & 52.0 & 71.7 \\
\hline Mean B & 56.1 & 50.8 & 46.3 & 40.4 & 36.1 & & 71.9 & 62.4 & 53.4 & 44.2 & 37.2 & \\
\hline L.S.D. $5 \%$ & $\mathbf{A}$ & 4.7 & B & 5.2 & AB & 10.4 & $\mathbf{A}$ & 2.6 & B & 4.7 & AB & 9.4 \\
\hline $1 \%$ & & 7.0 & & 6.9 & & 13.6 & & 3.9 & & 6.3 & & 12.6 \\
\hline \multicolumn{13}{|c|}{ S: Sand } \\
\hline
\end{tabular}

Table 12. Effect of growing media types and growth retardants on dry weight (g/1.5 $\mathrm{m}^{2}$ plot) of the third clipping of Lolium perenne, L. during 2008/2009 and 2009/2010.

\begin{tabular}{|c|c|c|c|c|c|c|c|c|c|c|c|c|}
\hline \multirow{3}{*}{$\begin{array}{l}\text { Growing } \\
\text { media types } \\
\text { Growth } \\
\text { retardant } \\
\text { concentrations } \\
\text { (ppm) }\end{array}$} & \multicolumn{12}{|c|}{ Dry weight (g/1.5 $\mathrm{m}^{2}$ plot) of the third clipping } \\
\hline & \multicolumn{8}{|c|}{ First season } & \multicolumn{4}{|c|}{ Second season } \\
\hline & $\begin{array}{c}\text { Control } \\
\mathbf{0}\end{array}$ & $\begin{array}{l}\text { CCC } \\
1000\end{array}$ & $\begin{array}{l}\text { CCC } \\
2000\end{array}$ & $\begin{array}{l}\text { Alar } \\
1000\end{array}$ & $\begin{array}{l}\text { Alar } \\
2000\end{array}$ & $\begin{array}{c}\text { Mean } \\
\text { A }\end{array}$ & $\begin{array}{c}\text { Control } \\
0\end{array}$ & $\begin{array}{l}\text { CCC } \\
1000\end{array}$ & $\begin{array}{l}\text { CCC } \\
2000\end{array}$ & $\begin{array}{l}\text { Alar } \\
1000\end{array}$ & $\begin{array}{l}\text { Alar } \\
2000\end{array}$ & $\begin{array}{c}\text { Mean } \\
\text { A }\end{array}$ \\
\hline S & 31.2 & 25.2 & 24.8 & 17.7 & 12.9 & 22.4 & 43.3 & 33.9 & 29.8 & 22.4 & 15.0 & 28.9 \\
\hline S + Comp. & 44.1 & 39.1 & 31.2 & 26.9 & 19.4 & 32.1 & 57.9 & 42.5 & 37.6 & 30.9 & 21.8 & 38.1 \\
\hline $\mathbf{S}+\mathbf{C}$ & 52.4 & 48.4 & 44.1 & 39.8 & 37.8 & 44.5 & 65.7 & 57.9 & 50.3 & 43.0 & 38.3 & 51.0 \\
\hline $\mathrm{C}$ & 68.1 & 62.9 & 59.0 & 54.8 & 47.5 & 58.5 & 81.8 & 71.8 & 63.8 & 56.1 & 49.8 & 64.7 \\
\hline Mean B & 49.0 & 43.9 & 39.8 & 34.8 & 29.4 & & 66.2 & 51.5 & 45.4 & 38.1 & 31.2 & \\
\hline L.S.D. $5 \%$ & A & 3.4 & B & 4.3 & AB & 8.6 & A & 4.5 & B & 5.8 & AB & 11.6 \\
\hline $1 \%$ & & 5.2 & & 5.8 & & 11.6 & & 6.8 & & 7.8 & & 15.6 \\
\hline
\end{tabular}

Table 13. Effect of growing media types and growth retardants on chlorophyll a content (mg / g F. W.) of Lolium perenne, L. during 2009 and 2010.

\begin{tabular}{|c|c|c|c|c|c|c|c|c|c|c|c|c|}
\hline \multirow{3}{*}{$\begin{array}{l}\text { Growing } \\
\text { media types } \\
\text { Growth } \\
\text { retardant } \\
\text { concentrations } \\
(\mathrm{ppm})\end{array}$} & \multicolumn{12}{|c|}{ Chlorophyll a content (mg / g F. W.) } \\
\hline & \multicolumn{9}{|c|}{ First season } & \multicolumn{3}{|c|}{ Second season } \\
\hline & $\begin{array}{c}\text { Control } \\
0\end{array}$ & $\begin{array}{l}\text { CCC } \\
1000\end{array}$ & $\begin{array}{l}\text { CCC } \\
2000\end{array}$ & $\begin{array}{l}\text { Alar } \\
1000\end{array}$ & $\begin{array}{l}\text { Alar } \\
2000\end{array}$ & $\begin{array}{c}\text { Mean } \\
\text { A }\end{array}$ & $\begin{array}{c}\text { Control } \\
0\end{array}$ & $\begin{array}{l}\text { CCC } \\
1000\end{array}$ & $\begin{array}{l}\text { CCC } \\
2000\end{array}$ & $\begin{array}{l}\text { Alar } \\
1000\end{array}$ & $\begin{array}{l}\text { Alar } \\
2000\end{array}$ & $\begin{array}{c}\text { Mean } \\
\text { A }\end{array}$ \\
\hline $\mathbf{S}$ & 2.223 & 2.271 & 2.297 & 2.290 & 2.311 & 2.278 & 2.281 & 2.339 & 2.372 & 2.401 & 2.423 & 2.363 \\
\hline S + Comp. & 2.394 & 2.470 & 2.522 & 2.496 & 2.540 & 2.484 & 2.502 & 2.548 & 2.593 & 2.626 & 2.680 & 2.590 \\
\hline $\mathbf{S}+\mathbf{C}$ & 2.443 & 2.281 & 2.524 & 2.536 & 2.551 & 2.507 & 2.554 & 2.613 & 2.640 & 2.680 & 2.717 & 2.641 \\
\hline C & 2.531 & 2.568 & 2.601 & 2.592 & 2.635 & 2.585 & 2.692 & 2.724 & 2.771 & 2.752 & 2.811 & 2.750 \\
\hline Mean B & 2.398 & 2.448 & 2.486 & 2.479 & 2.509 & & 2.507 & 2.556 & 2.594 & 2.615 & 2.658 & \\
\hline L.S.D. $\quad 5 \%$ & A & 0.062 & B & 0.051 & $\mathbf{A B}$ & 0.102 & A & 0.077 & B & 0.042 & AB & 0.084 \\
\hline $1 \%$ & & 0.094 & & 0.069 & & 0.138 & & 0.117 & & 0.056 & & 0.112 \\
\hline \multicolumn{13}{|c|}{ S: Sand } \\
\hline
\end{tabular}


Table 14. Effect of growing media types and growth retardants on chlorophyll b content (mg / g F. W.) of Lolium perenne, L. during 2009 and 2010.

\begin{tabular}{|c|c|c|c|c|c|c|c|c|c|c|c|c|}
\hline \multirow{3}{*}{$\begin{array}{c}\text { Growing } \\
\text { media types } \\
\text { Growth } \\
\text { retardant } \\
\text { concentrations } \\
\text { (ppm) }\end{array}$} & \multicolumn{12}{|c|}{ Chlorophyll b content (mg / g F. W.) } \\
\hline & \multicolumn{9}{|c|}{ First season } & \multicolumn{3}{|c|}{ Second season } \\
\hline & $\begin{array}{c}\text { Control } \\
\mathbf{0}\end{array}$ & $\begin{array}{l}\text { CCC } \\
1000\end{array}$ & $\begin{array}{l}\text { CCC } \\
2000\end{array}$ & $\begin{array}{l}\text { Alar } \\
1000\end{array}$ & $\begin{array}{l}\text { Alar } \\
2000\end{array}$ & $\begin{array}{c}\text { Mean } \\
\text { A }\end{array}$ & $\begin{array}{c}\text { Control } \\
0\end{array}$ & $\begin{array}{l}\text { CCC } \\
1000\end{array}$ & $\begin{array}{l}\text { CCC } \\
2000\end{array}$ & $\begin{array}{l}\text { Alar } \\
1000\end{array}$ & $\begin{array}{l}\text { Alar } \\
2000\end{array}$ & $\begin{array}{c}\text { Mean } \\
\text { A }\end{array}$ \\
\hline $\mathbf{S}$ & 0.743 & 0.768 & 0.408 & 0.808 & 0.834 & 0.791 & 0.811 & 0.850 & 0.886 & 0.834 & 0.891 & 0.854 \\
\hline S + Comp. & 0.817 & 0.842 & 0.860 & 0.868 & 0.892 & 0.856 & 0.864 & 0.892 & 0.922 & 0.888 & 0.952 & 0.904 \\
\hline $\mathbf{S}+\mathbf{C}$ & 0.882 & 0.906 & 0.933 & 0.916 & 0.955 & 0.918 & 0.914 & 0.932 & 0.974 & 0.960 & 0.996 & 0.955 \\
\hline C & 0.902 & 0.927 & 0.952 & 0.941 & 0.969 & 0.938 & 0.945 & 0.972 & 0.996 & 1.004 & 1.017 & 0.987 \\
\hline Mean B & 0.836 & 0.861 & 0.887 & 0.883 & 0.913 & & 0.884 & 0.912 & 0.945 & 0.922 & 0.964 & \\
\hline $\begin{array}{ll}\text { L.S.D. } & 5 \% \\
\end{array}$ & $\mathbf{A}$ & 0.018 & B & 0.015 & $\mathbf{A B}$ & 0.030 & $\mathbf{A}$ & 0.022 & B & 0.017 & $\mathbf{A B}$ & 0.034 \\
\hline $1 \%$ & & 0.027 & & 0.020 & & 0.040 & & 0.033 & & 0.023 & & 0.046 \\
\hline
\end{tabular}

Table 15. Effect of growing media types and growth retardants on carotenoids content (mg / g F. W.) of Lolium perenne, L. during 2009 and 2010.

\begin{tabular}{|c|c|c|c|c|c|c|c|c|c|c|c|c|}
\hline \multirow{3}{*}{$\begin{array}{c}\text { Growing } \\
\text { media types } \\
\text { Growth } \\
\text { retardant } \\
\text { concentrations } \\
(\mathrm{ppm})\end{array}$} & \multicolumn{12}{|c|}{ Carotenoids content (mg / g F. W.) } \\
\hline & \multicolumn{8}{|c|}{ First season } & \multicolumn{4}{|c|}{ Second season } \\
\hline & $\begin{array}{c}\text { Control } \\
0\end{array}$ & $\begin{array}{l}\text { CCC } \\
1000\end{array}$ & $\begin{array}{l}\text { CCC } \\
2000\end{array}$ & $\begin{array}{l}\text { Alar } \\
1000\end{array}$ & $\begin{array}{l}\text { Alar } \\
2000\end{array}$ & $\begin{array}{c}\text { Mean } \\
\text { A }\end{array}$ & $\begin{array}{c}\text { Control } \\
0\end{array}$ & $\begin{array}{l}\text { CCC } \\
1000\end{array}$ & $\begin{array}{l}\text { CCC } \\
2000\end{array}$ & $\begin{array}{l}\text { Alar } \\
1000\end{array}$ & $\begin{array}{l}\text { Alar } \\
2000\end{array}$ & $\begin{array}{c}\text { Mean } \\
\text { A }\end{array}$ \\
\hline $\mathbf{S}$ & 0.962 & 1.006 & 1.027 & 1.042 & 1.071 & 1.021 & 1.042 & 1.053 & 1.122 & 1.106 & 1.157 & 1.096 \\
\hline S + Comp. & 1.020 & 1.052 & 1.081 & 1.060 & 1.098 & 1.062 & 1.124 & 1.151 & 1.185 & 1.204 & 1.228 & 1.178 \\
\hline $\mathbf{S}+\mathbf{C}$ & 1.092 & 1.131 & 1.152 & 1.170 & 1.198 & 1.149 & 1.140 & 1.192 & 1.226 & 1.211 & 1.250 & 1.204 \\
\hline $\mathbf{C}$ & 1.118 & 1.142 & 1.169 & 1.188 & 1.240 & 1.171 & 1.219 & 1.250 & 1.289 & 1.304 & 1.341 & 1.281 \\
\hline Mean B & 1.048 & 1.083 & 1.107 & 1.115 & 1.152 & & 1.131 & 1.162 & 1.206 & 1.206 & 1.244 & \\
\hline L.S.D. & A & 0.030 & B & 0.016 & AB & N.S. & A & 0.047 & B & 0.028 & $\mathbf{A B}$ & N.S. \\
\hline $1 \%$ & & 0.045 & & 0.022 & & N.S. & & 0.071 & & 0.038 & & N.S. \\
\hline \multicolumn{13}{|c|}{ S: Sand } \\
\hline
\end{tabular}

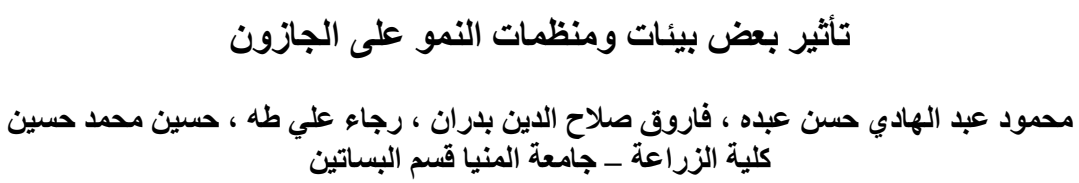

* تهدف الدراسة الحالية إلى دراسة إمكانية زراعة مسطح الجازون في التربة الرملية بعد إضافة محسنات التربة إليها كبديل للتربة الطينية وذللك بالإضافة إلى تقليل مصاريف القص المتتالي والحفاظ على الوقت المستغل لهذا القص المتكرر وذللك باستعمال بعض مؤخرات النمو وقد تم

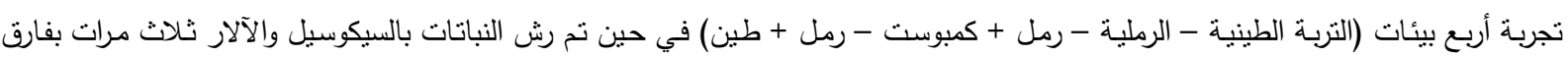
أربع أسابيع بين كل رشتين بتركيزات 1000 و 2000 جزء في المليون لكل منها.

* بالنسبة لبيئات النمو فقد حدث زيادة كبيرة ومعنوية في كل الصفات الخضرية الأربعة تحت الدراسة (طول النبات ونسبة التغطية والوزن الطازج والجاف) بالإضـافة إلى التثلاث صبغات للبنـاء الضـوئي نتيجة الزراعة في التربـة الطينية بالمقارنـة بالبيئات الثناثل الأخرى ، ومن الناحية

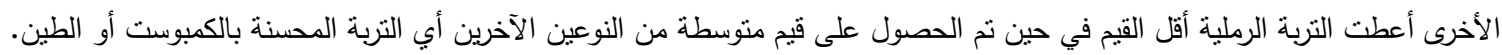

* نتج عن استعمال المعاملات الأربعة كمؤخرات للنمو نقص واضح في كل من طول النبات والوزن الطازج والجاف بينما حدثت زيادة ملموسة في صفة نسبة التغطية وكذلك صبغات البناء الضوئي ولقد وجد أن الآلار كان أكثر تأثبرا من السيكوسيل. * التداخل بين بيئات النمو ومؤخرات النمو كان في الغالب معنويا للصفات الخضرية وصبغات البناء الضوئي. * يمكن بزراعة مسطح الجازون في تربة رملية بعد إضافة الكمبوست إليها (2 : 1 بالحجم) مع إمداد النبات بمؤخر النمو الآلار بتركيز 2000 جزء في المليون ثلاث مرات وذلك للحصول على نقص معقول في طول النبات وكذللك زيادة سريعة في نسبة التغطية. 